\title{
Getting under your skin: botfly myiasis
}

\author{
Rhys Watkins, ${ }^{1}$ Mallappa Kolar, ${ }^{1}$ David Ralston ${ }^{2}$
}

${ }^{1}$ Department of Plastic Surgery, Sheffield Teaching Hospitals NHS Foundation Trust, Sheffield, South Yorkshire, UK

${ }^{2}$ Department of Plastic Surgery, University of Sheffield, Sheffield, South Yorkshire, UK

Correspondence to Dr Rhys Watkins,

rhys_watkins@btinternet.com

Accepted 8 May 2019

\section{DESCRIPTION}

Returning to the UK after a trip to Argentina, a woman in her 50 s felt generally unwell. The patient was initially treated by her general practitioner (GP) with oral antibiotics for a left-sided ear infection. At around the same time, she also became aware of two itchy, raised lesions on the anterior and posterior aspects of the left side of her scalp, which her GP diagnosed as cysts and treated with a separate course of antibiotics when she returned a week later.

However, over the next 3 weeks, the 'cysts' grew in size, discharging clear, odourless fluid, and producing intermittent stabbing pains. Further investigation was therefore sought.

By the time she was admitted to the hospital, 7 weeks after returning to the UK, the cysts were approximately $2 \mathrm{~cm}$ in diameter, raised, but not inflamed, each with a noticeable central punctum (figure 1). The patient also reported being able to sense movements within her scalp around the affected regions. Bloods taken prior to admission were all normal, other than a mildly raised thyroid-stimulating hormone level from chronic hypothyroidism. A mid-stream urine also revealed no anomalous findings.

A differential diagnosis of myiasis with two human botfly (Dermatobia hominis) larvae was proposed, and a plan was made to extract them by smothering the cysts with Vaseline. This would occlude the larvae's central punctum, through which they breathe, theoretically forcing them to come up to the surface for air and exit the host. ${ }^{1}$ The anterior larva was successfully removed by this method (figure 2), but the posterior larva had died in situ and was inaccessible.

The patient was taken to the theatre by the plastic surgery team the following day and the remaining larva was removed under local anaesthetic

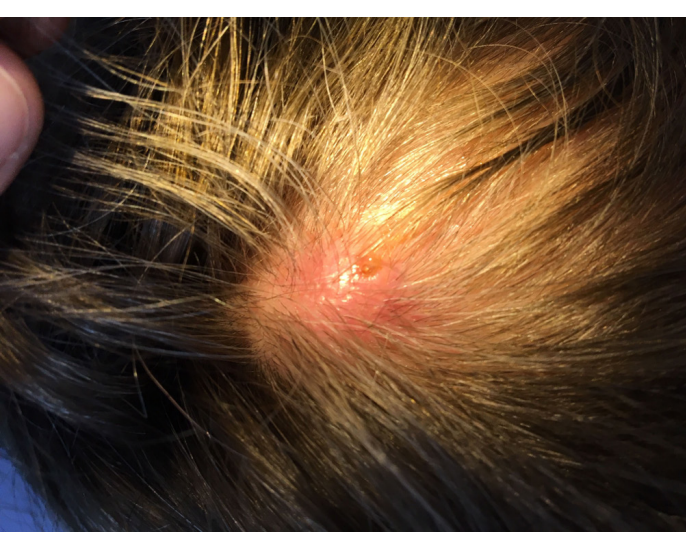

Figure 1 Photo of the patient's scalp prior to surgery. The larva's breathing hole is visible.

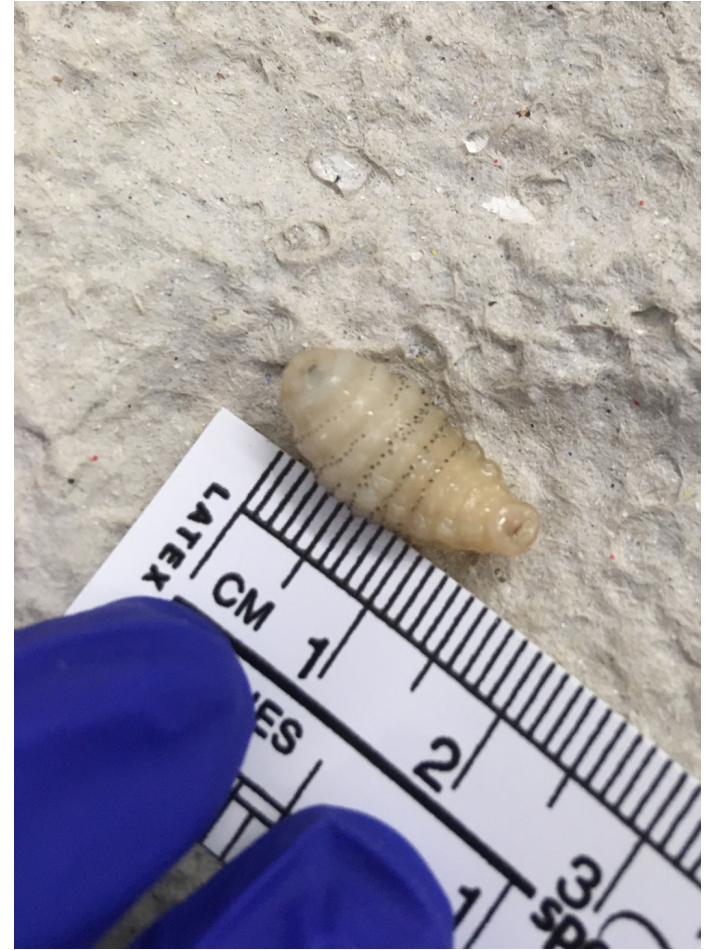

Figure 2 The first botfly larva, extracted on the ward after application of Vaseline, measuring $1.5 \times 0.5 \mathrm{~cm}$.

(figure 3). Both wounds were washed out with saline and antibiotic ointment was applied to the scalp. The patient was advised to take lukewarm showers twice daily and to continue to apply ointment until the wounds scabbed over.

Botflies are predominantly found in Central and Southern America, and infection with the larvae is known as myiasis. This particular case is atypical as botfly infestation in humans usually involves a single larva. ${ }^{2}$ The patient had travelled around Iguazu Falls and recalled being bitten by mosquitoes on several occasions. The larvae of botflies reach their hosts through a process called phoresis, whereby botflies capture and deposit their eggs on a blood-feeding insect (such as a mosquito) and these eggs are, in turn, transmitted to the host during a mosquito's blood meal. The warmth of the host's body triggers the fly eggs to hatch, and the larvae then burrow into the subcutaneous tissue. ${ }^{3}$ Here they can remain anywhere between 4 and 18 weeks. The larvae then exit and pupate in the soil. Following extraction, the wound site classically heals well. The patient in this scenario could have waited for the botfly larvae to leave her body naturally. However, this was neither acceptable to the patient nor practical after one larva died in situ, and so medical intervention was required. 


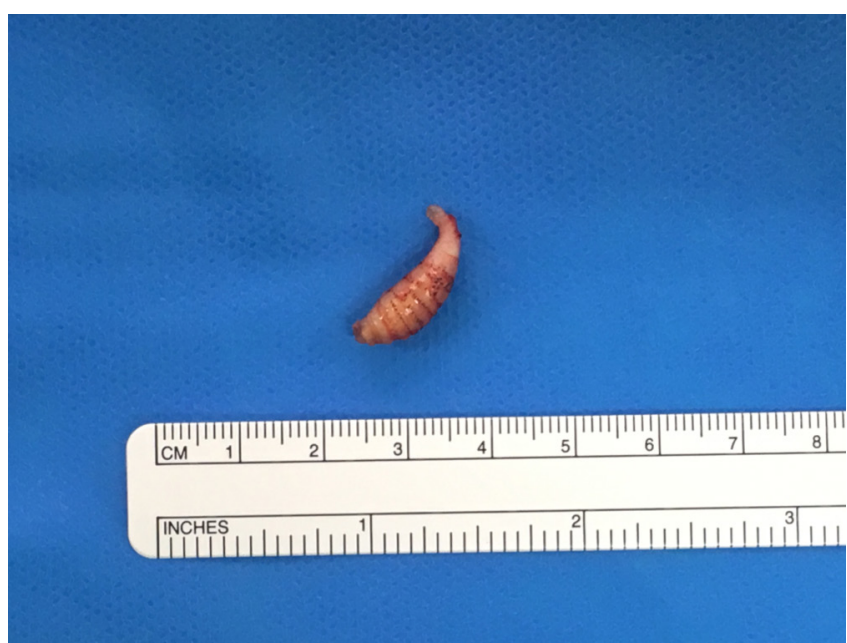

Figure 3 The second botfly larva, removed following surgical excision, with breathing tube intact.

\section{Learning points}

- Consider a diagnosis of botfly myiasis in any patient returning from the Americas with a new raised, pruritic skin lesion. Myiasis is rare in the UK but is a relatively common dermatological condition of travellers to tropical regions.

- Botfly myiasis is typically resistant to treatment with oral antibiotics.

- Human botfly infestation is not usually harmful, but incomplete extraction may trigger a foreign body reaction or may lead to secondary bacterial infection. ${ }^{3}$ Attempting to squeeze out the botfly is not advised as this can rupture the larva and cause an anaphylactic reaction. ${ }^{2}$

Contributors RW (FY1 doctor) was responsible for writing and submitting the article. MK (registrar in plastic surgery) reviewed the article prior to submission. DR (consultant in plastic surgery and honorary senior lecturer) reviewed the article and provided images for figures 1 and 3.

Funding The authors have not declared a specific grant for this research from any funding agency in the public, commercial or not-for-profit sectors.

\section{Patient's perspective}

When I first presented to my GP following my return from Argentina, it was with left-sided ear pain and raised lymph glands on the same side of my neck. The lumps on my head felt small and, although itchy and irritating, weren't a cause of concern to me initially.

As time went on and the ear infection was cleared by antibiotics, my focus, and that of my GP, shifted to the continuing lymph gland issue and, to a lesser extent, the lumps on my head, which had grown in size and were becoming more irritating and painful and were emitting fluid. Although a friend had suggested the idea of a parasitic infection quite early on, I accepted the (different) GP's diagnosis of cysts and didn't look into the possibility of a parasite myself until the lumps had got the point of being very painful and difficult to live with.

In retrospect, having a firm diagnosis of head cysts was unfortunate as it delayed me from exploring the issue myself. Once I did, I was able to suggest the possibility of human botfly to my GP, who was able to refer me to the Hallamshire the next day, which I was very grateful for.

The consultant in Ear, Nose and Throat, who I saw about my lymph glands after the removal of the botfly larvae, noted that the glands could have been affected by the larvae.

I feel that future patients with human botfly larvae infection would be best dealt with by going directly to minor surgery to remove the living larvae and to have the space occupied by them cleaned out.

Competing interests None declared.

Patient consent for publication Obtained.

Provenance and peer review Not commissioned; externally peer reviewed.

\section{REFERENCES}

1 Török EM, Moran E, Cooke F. Ectoparasites: In. Oxford Handbook of Infectious Diseases and Microbiology. 2nd ed. Oxford: Oxford University Press, 2016.

2 Nduka JC, Mcnair R. Human botfly infestation: the tip of the iceberg. BMJ Case Rep 2014;2014:doi: ber2014205890.

3 Ofordeme KG, Papa L, Brennan DF. Botfly myiasis: a case report. CJEM 2007;9:380-2.

Copyright 2019 BMJ Publishing Group. All rights reserved. For permission to reuse any of this content visit

https://www.bmj.com/company/products-services/rights-and-licensing/permissions/

BMJ Case Report Fellows may re-use this article for personal use and teaching without any further permission.

Become a Fellow of BMJ Case Reports today and you can:

- Submit as many cases as you like

- Enjoy fast sympathetic peer review and rapid publication of accepted articles

- Access all the published articles

- Re-use any of the published material for personal use and teaching without further permission

Customer Service

If you have any further queries about your subscription, please contact our customer services team on +44 (0) 2071111105 or via email at support@bmj.com.

Visit casereports.bmj.com for more articles like this and to become a Fellow 